\title{
The Arab Spring Through Malaysian Youth 'Eyes': Knowledge, Perceptions and Influences
}

\author{
Mohd Irwan Syazli Saidin \\ School of History, Politics and Strategy, \\ Faculty of Social Sciences and Humanities, \\ Universiti Kebangsaan Malaysia, Malaysia
}

Doi: $10.2478 / \mathrm{mjss}-2018-0012$

\section{Abstract}

This paper examines the attitude of Malaysian youth towards the 'Arab Spring' events in the Middle East and North Africa. In particular, it explores the knowledge and perceptions of a selected young generation in Malaysia towards the 'Arab Spring' as well as considering how the events influence their attitudes towards regime change, democracy and political stability. The major involvement of Malaysian youth in a series of mass protests ("BERSIH") against the ruling government, were perceived by numerous local and foreign journalists as an attempt to create a "Malaysian Spring". However, there have been strong opinions voiced by the Malaysian authorities suggesting that there was no basis for presuming an 'Arab Spring' impact in the context of the Malaysian experience. This raises the question of the relationship between the 'Arab Spring' and Malaysian youth. In so doing, both quantitative and qualitative methods were applied through a questionnaire based-survey involving 607 respondents as well as 10 in-depth interviews with selected Malaysian youth leaders. The outcome of this research shows that a number of youth believing that they were inspired by the acts of mass street protests during the 'Arab Spring'. However, the fear of political instability which is currently evident in the post-Arab Spring led to some respondents favouring political stability rather than regime change. Overall, this empirical research found that the majority of Malaysian youth are supportive of a free and democratic election as a relevant medium for political change, rather than overthrowing the current regime via civil disobedience.

Keywords: The Arab Spring, Malaysian Youth, Political Stability, Democracy and Regime Change

\section{Introduction}

Several years ago, the Middle East and North Africa region was tested by the so-called 'wave of democratic uprising', popularly known as the Arab Spring phenomenon. Mass street protests occurred in Tunisia, Egypt, Libya, Yemen, Syria and Bahrain. Minor protests were also reportedly held in other major cities of Morocco and Algeria. The outcome of these actions varied from one country to another. In Tunisia, the removal of Ben Ali seemed to pave the way for Tunisian politics to become relatively more democratic via the practice of a free and competitive election. Meanwhile in Egypt, the current political instability and economic situation are in contrast to what people actually expected since the resignation of Mubarak in January 2011. In Syria, Libya and the Yemen, the post-Arab Spring has witnessed complicated circumstances ranging from a series of civil wars and proxy fights between great superpowers and the emergence of ISIS. The genesis of the Arab Spring was deemed to transform all the affected states into more democratic and less dictatorial states with more effective economic development. However, the journey to reach these main goals seems to have a long way to go. The only exception is Tunisia, where the practice of free and fair elections is currently in place and was thus recognised by the Freedom House in 2015 as one of 
the emerging 'democratic' states in the Middle East and North Africa region. Having witnessed the uprisings in the Arab world, there were studies by scholars around the globe to assess the global impact of the Arab Spring beyond the Middle East and North Africa, particularly in the Asian continent. Most of the discussions considered elements of civil resistance and the effectiveness of social media as a new platform for political change. Research by Saikal and Acharya (2014) found that the Arab Spring events have indirectly influenced and inspired several pro-democracy movements in Myanmar and China. Meanwhile, in Malaysia, during the launch of the Arab Spring circa 2011, a number of people excitedly paid attention to the unfolding events to see if there were any rewarding results from the struggle of Arab citizens for political reform (Bakar, 2012). The anticipation was rewarded when the news of the falls of Ben Ali and Mubarak rapidly circulated on social media including Facebook and Twitter.

Concurrently, with the recent growing popularity of street protest action in Malaysia against the ruling government, especially under the current premiership of Najib Razak, there are concerns being expressed by the regime that Malaysian youth activists championed by student movements and mobilised by local political parties, were somehow trying to imitate the way that Arab youth ${ }^{1}$ achieved political change during the Arab Spring. This statement was claimed as baseless and denied by the opposition party and the Malaysian pro-democracy movement leaders, Maria Chin and Mohamad Sabu, who argued that the previous street protests in Malaysia were held in a peaceful manner and had been practiced long before the launch of the Arab Spring in the Middle East $^{2}$. The 'connection' between the Arab Spring and civil protest in Malaysia became prevalent when Abdul Hadi Awang, the current president of Pan-Malaysian-Islamic Party (PAS), made a statement in 2016 which appeared to be a direct warning to Malaysian youth, as well as other opposition parties and NGOs in Malaysia, not to create a "Malaysian Spring" for the sake of overthrowing the existing ruling government ${ }^{3}$. As Pang (2014) points out, the launch of the Arab Spring revolutions fuelled the Malaysian government's paranoia regarding the possibility of similar uprisings in Malaysia if the critical voices amongst its citizens, mainly among the grassroots, go unheard. These situations led to the polemic of the Arab Spring in the Malaysian political landscape and its potential impact on the attitudes of Malaysian youth. Nevertheless, the following questions remain unanswered: 1) To what extent did Malaysian youth know about the Arab Spring phenomenon? 2) To what extent has the Arab Spring phenomenon influenced their attitudes toward the issues of regime change, democracy and political stability in Malaysia? 3) What lessons can Malaysian youth activists learn from the Arab Spring? Therefore, this paper will empirically present the knowledge and views of Malaysian youth towards the Arab Spring phenomenon. The aim is primarily to show how the young generation in Malaysia perceive the Arab Spring and to determine whether the events have impacted their attitude to various political issues (as mentioned above) in Malaysia. This paper is in fact the first empirical research conducted on the Arab Spring among Malaysian youth activists and as such their attitudes currently remain unclear to the authorities as well as to the public and academia.

\section{Youth, Politics and Civil Resistance in Malaysia}

Youth in Malaysia have always played an important role in the development of the Malaysian political system. The increasing technology available on social media have allowed youth to become more aware of current political issues that happen in Malaysia, as well as around the world. The Malaysian constitution via the Youth Development Act (668) defines youth as those between the ages of 15 and 40. According to statistics issued by the Malaysian Department of Statistics (2015), youth in Malaysia currently make up at approximately 55 percent of the

\footnotetext{
${ }^{1}$ Huge turnout and participation from youth, mostly university students and tech-savvy youth during the Arab Spring was considered one of the factors which successfully secured the uprisings in Tunisia and Egypt. The emergence of youth capable of producing unprecedented changes marks the coming of a new generation of critics and rebels in the Arab world (Kassab, 2014).

${ }^{2}$ Fieldwork at the Coalition for Clean and Fair Election (Bersih) roadshow, Shah Alam, Malaysia. 3 November 2016. The statements were originally quoted from Mohamad Sabu's and Maria Chin's speeches at the event.

${ }^{3}$ Official statement from the PAS president, Abdul Hadi Awang, November 2016.
} 
population. The interest of Malaysian youth in politics can be seen in their active participation, as well as direct affiliation, to local political parties and NGOs such as UMNO, PAS, PKR, DAP, AMANAH and $\mathrm{ABIM}^{4}$. These organisations have each established their own youth wings which serve towards their succession planning as well as providing ground support for political activism, especially during a pre-election period. The recent leaked news from highly reputable media organisations such as The Wall Street Journal and the BBC have revealed the corruption and power abuse practiced by the existing Malaysian government, particularly relating to the infamous monetary scandal of $1 \mathrm{MDB}^{5}$ which involved Najib Razak and triggered a large crowd of youth to occupy the streets of Kuala Lumpur in November 2016 as a medium to show their anger and protest. As directly quoted from the Wall Street Journal website ${ }^{6}$ :

"Global investigators believe more than \$1 billion entered Malaysian Prime Minister Najib Razak's personal bank accounts, much of it from state investment fund $1 M D B$. The scandal has caused a political crisis and threatens to upend years of one-party rule in the country."

The protesters demanded the immediate resignation of Najib Razak as Prime Minister of Malaysia. Regarding street protest and civil resistance in Malaysia, the trend for so called 'people's power' against the ruling government has expanded consistently, starting with the reformation movement (reformasi) in 1998 and until recently (Bersih, 2016). Part of these civil protests, the so called Coalition of Clean and Fair Election, dubbed the "Bersih" Movement, gained huge support from Malaysian youth across the country. In 2012, the movement managed to gather almost half a million participants to join its political rally prior to the $13^{\text {th }}$ general election. As reported by Fisher (2012), it was estimated that around 500,000 'yellow-shirt' people took to the streets on 28 April 2012 to call for substantial change to the voting system, as well as political and economic reform. With strong support from most opposition parties and NGOs, the rally was perceived as the largest mass mobilisation and political protest in the history of Malaysia. Having witnessed the enormous turnout, some observers and foreign journalists, for example Currie (2012) accused the protest organised by Bersih in 2012 as an attempt to create a "Malaysian Spring" after being inspired by the uprisings in the Middle East and North Africa. Her statement seems in line with Diamond (2012), a prominent American political scientist, by suggesting that the impact of the Arab Spring might extend to the region of East Asia and thus also affect Malaysia given the continuous practice of 'semi-democracy' and some sort of 'competitive authoritarian' elements. The government however rejected the possibility of an Arab Spring style revolution and political change taking place in any part of Malaysia. For them, there was no basis for Malaysians, especially the youth to presume that what had happened in the Middle East would happen in the Malaysian context ${ }^{7}$. Nevertheless, the arguments from both parties were not supported with any empirical evidence, rather they were merely personal opinions thus making the statements defenseless. Therefore, this research chose to undertake intensive on-the-ground field work to obtain as many participant responses as possible in order to provide insights on the polemics of the Arab Spring among Malaysian youth. The next section will discuss in further detail the methodology that was used in this research.

\footnotetext{
${ }^{4}$ UMNO: United Malays National Organisation. PKR: Parti Keadilan Rakyat / People Justice Party. DAP: Democratic Action Party. AMANAH: The National Trust Party. ABIM: Angkatan Belia Islam Malaysia / The Islamic Youth Movement of Malaysia.

${ }^{5}$ The $1 M D B$ scandal is a high profile case of corruption and power abuse which claimed to involve the so called 'Malaysian official no 1' and is currently under investigation by the United States Department of Justice and Swiss authorities.

${ }^{6}$ The Wall Street Journal (2016). Malaysia Corruption Scandal, 1MDB \& Najib Razak Latest News. [Online] Available: $h$ ttp://www.wsj.com/specialcoverage/malaysia-controversy. (April 122017)

${ }^{7}$ For more details please see http://www.thestar.com.my/news/nation/2013/07/03/najib-tun-razak-arab-springbbc-interview.
} 


\section{Method of the Study}

This research applies the 'Explanatory Sequential Mixed-Method' (ESMM) as outlined by John Creswell (2014) using both quantitative and qualitative approaches ${ }^{8}$. The ESMM requires a researcher to conduct quantitative research first, then follow up with a qualitative phase to explain the data in more detail. For the quantitative method, a questionnaire based-survey was the single instrument used. This involved a sample of 607 selected Malaysian youth. This research refers to the formula and table created by Krejcie and Morgan (1970) in order to determine the sample size needed to be representative of a given population, in this case the selected Malaysian youth. The sample of the study represented approximately 23,434 Malaysian youth in the areas of Selangor and Kuala Lumpur, Malaysia. The selection of Malaysian youth aged between 18 to 35 years old was based on certain criteria, for example having an affiliation to a political party or NGO, as well as past involvement in any civil protest within the country. The main objective of the questionnaire's distribution was to explore the Malaysian youth's perceptions toward the Arab Spring, as well as to investigate any potential impact of the events on their attitudes towards the issue of regime change, democracy and political stability. All data obtained from the questionnaire was coded and descriptively analysed using the Statistical Package for Social Sciences (SPSS), mainly through the simple frequency and crosstab option. Since the nature of this research was of an exploratory type, there was no SPSS test applied to the data. For the qualitative method, the researcher conducted several in-depth interviews with selected Malaysian youth who had previously participated in demonstrations along with direct observation of programmes organised by the Bersih throughout the country. Data from interviews was recorded, transcribed and analysed by using NVIVO software in order to view the emerging trend of responses from participants.

\subsection{Respondents' Backgrounds}

In the early section of the questionnaire, there were a few questions involving the background of respondents such as gender, level of education, last place of education and involvement in civil protest, local political parties or NGOs. All these aspects are significant as added value to assess any differences in the trend and pattern of statistical data. Table 1 gives details of the distribution of the sample among male and female respondents. Of the 607 respondents, 424 are male youth which constitutes 69.9 percent of the total, while the number of female respondents is 183 (30.1 percent). The researcher believes that the reason behind this visible gap between the number of male and female respondents was due to a high percentage of female youth who decided to turn down any participation in the study for personal reasons.

Table 1. Gender

\begin{tabular}{ccc}
\hline Gender & Frequency & Percentage \\
\hline Male & 424 & 69.9 \\
Female & 183 & 30.1 \\
Total & 607 & 100.0 \\
\hline
\end{tabular}

Source: Field Research 2016

Table 2 gives more detail about the sample by level of education. The majority of respondents have a Bachelors Degree (337), followed by those with a Diploma (137), Secondary School education (80), a Masters degree (48) and a PhD (5).

\footnotetext{
${ }^{8}$ It is considered sequential, since the initial quantitative phase of the research is followed by a qualitative phase. The researcher first conducts quantitative research, analyses the results from the questionnaire and then builds on the results to explain them in more detail with qualitative research - the interviews. For more detail please see John Creswell (2014). Research Design: Qualitative, Quantitative and Mixed Methods Approaches. 4th ed. Los Angeles: Sage.
} 
Table 2. Level of Education

\begin{tabular}{lcc}
\hline Level & Frequency & Percentage \\
\hline SPM (Secondary School) & 80 & 13.2 \\
A-level/Diploma & 137 & 22.6 \\
Bachelors Degree & 337 & 55.5 \\
Masters Degree & 48 & 7.9 \\
PhD & 5 & 0.8 \\
Total & 607 & 100.0 \\
\hline
\end{tabular}

Source: Field Research 2016

With regard to their last place of education, 89.3 percent of respondents graduated from local universities, while the remaining 10.7 percent were considered as overseas graduates. The majority of these overseas graduates studied in the Middle East and North Africa region (specifically Egypt, Morocco and Jordan), mostly in the field of Arab and Islamic studies. There were also a significant number of respondents from various fields who graduated from English speaking countries such as the United Kingdom, the United States of America, Australia and the Republic of Ireland. A small number of respondents also reported studying medicine in Indonesia and India. Table 3 shows details of the respondents' last place of education by specific country.

Table 3. Last Place of Education

\begin{tabular}{lcc}
\hline Location (country) & Frequency & Percentage \\
\hline Malaysia & 542 & 89.3 \\
Egypt & 15 & 1.3 \\
Morocco & 8 & 5.0 \\
Jordan & 2 & 0.3 \\
Australia & 4 & 0.7 \\
United Kingdom & 10 & 1.6 \\
United States of America & 4 & 0.7 \\
Rep. of Ireland & 1 & 0.2 \\
India & 3 & 0.5 \\
Indonesia & 4 & 0.7 \\
Other & 14 & 2.3 \\
Total & 607 & 100.0 \\
\hline
\end{tabular}

Source: Field Research 2016

To ensure that the selected respondents were relevant for this study, the researcher decided to ask a straightforward question about their past involvement in any political protest or demonstration in the country, as well as their participation in any political party or NGO. However, given the sensitive nature of these questions (as perceived by respondents), the details of the responses for example the exact name, place and date of event and participating organisation will not be exposed, as agreed on the consent form. Overall, 597 respondents (98.4 percent) had attended civil protests and demonstrations, most notably the series of Bersih (1.0, 2.0. 3.0, 4.0 and 5.0) rallies as well as being members of local political parties or NGOs in Malaysia. The remaining 10 respondents (1.6 percent) have never participated in any political rally and did not have any official affiliation to any political organisation in the country. 


\section{Finding and Discussion}

\subsection{Respondents' Knowledge of the Arab Spring Phenomenon}

In order to identify the awareness of selected Malaysian youth towards the Arab Spring phenomenon, the following question was asked in the questionnaire: "Do you know anything about the people's upheaval in the Middle East and North African countries (the 'Arab Spring') that started in the year 2011?" 494 respondents (81.38 percent) answered 'yes' while 113 respondents (18.62 percent) believed that they had never heard of such uprisings occurring in the Arab world. Figure 1 below summarises the responses from selected Malaysian youth regarding their knowledge towards the Arab Spring events.

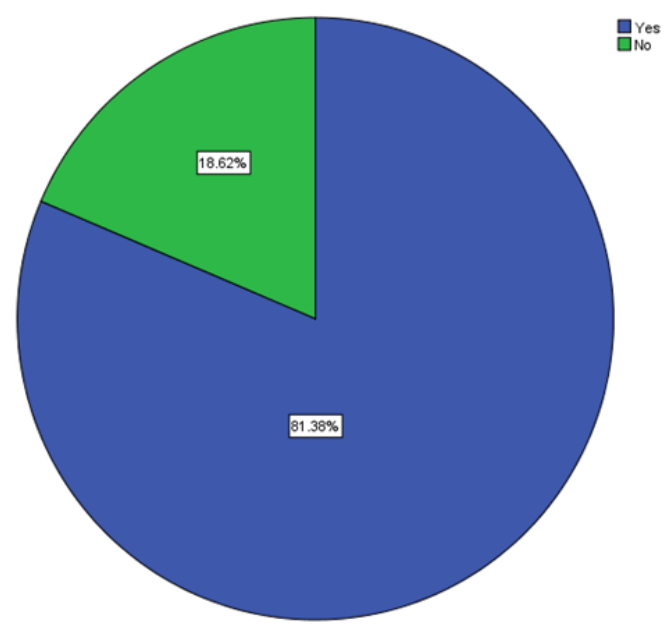

Figure 1. Respondents' Knowledge of the Arab Spring Phenomenon in the Middle East and North Africa

\subsection{Source of Information Regarding the Arab Spring Events}

Table 4. Source of Information Regarding the Arab Spring Events

\begin{tabular}{lc}
\hline Source & Frequency \\
\hline Television & 352 \\
Newspaper & 282 \\
Internet/Social Media & 443 \\
Radio & 75 \\
Book & 129 \\
Journal Article & 101 \\
Forum/Seminar/Talk/Lecture & 329 \\
Lecturer/Teacher/Friends/Family & 277 \\
Self-Experience & 13 \\
\hline
\end{tabular}

Source: Field Research 2016

For those 494 respondents who knew about the Arab Spring, their sources of information were varied as can be seen from Table 4 above. In particular, 443 respondents considered the role of social media and the internet (for instance Facebook and Twitter) as the most resource-rich mediums to stream information on the Arab Spring. 352 respondents used to watch television, 
mainly certain world news channels to obtain information about the Arab uprisings, while 75 respondents heard similar news on the radio. 329 respondents attended a seminar, forum or lecture in various places, mostly during their years as a university student, to learn more about the uprisings, while 282 respondents simply read a newspaper for the same purpose. Academic books and journal articles were also treated as a foundation for knowledge on the Arab Spring, while 13 respondents referred to their personal experience whilst staying in Egypt during the launch of the Arab Spring.

\subsection{Perceptions of Respondents towards the Arab Spring Phenomenon}

Generally speaking, perception can be defined as an awareness of something through observation. Perception also means the way in which an issue is understood, interpreted or regarded - in this case the Arab Spring. In order to explore the perception of youth in Malaysia towards the Arab Spring, this research distributed a Likert-scale type of questionnaire which consisted of five main questions relating to the basic facts of the event with five selections for the respondents' answers: Strongly agree; agree; neutral/neither disagree nor agree; disagree; strongly disagree. The following section will discuss in further detail the questions and respondents' responses.

\subsubsection{The First Question: Perception that the Arab Spring was the People's Upheaval against Autocratic Rulers}

Prior to the launch of the Arab Spring, most of the Arab states, including Tunisia, Egypt, Syria, Libya and Yemen, were ruled by long serving autocratic rulers (Gelvin, 2012; Olivier, 2012; Storm, 2014). For the majority of Malaysian youth activists in the study (85 percent), the Arab Spring protests were certainly a civil resistance against these oppressive leaders. 12 percent of respondents preferred to remain neutral in viewing the Arab Spring as the citizen's disapproval of their so-called 'undemocratic' leaders. Only 3 percent of respondents disagreed with the question being asked. Table 5 below shows more detail about the respondents' feedback.

Table 5. Respondents' Perceptions that the Arab Spring was the People's Upheaval against Autocratic Rulers

\begin{tabular}{lcc}
\hline Category & Frequency & Percentage \\
\hline Strongly Disagree & 8 & 1.6 \\
Disagree & 7 & 1.4 \\
Neither Disagree Nor Agree & 59 & 12.0 \\
Agree & 182 & 36.9 \\
Strongly Agree & 237 & 48.1 \\
\hline
\end{tabular}

Source: Field Research 2016

\subsubsection{The Second Question: Perception that the Arab Spring was a Non-Violent Resistance Movement}

The concept of non-violent civil resistance was popularised by Mahatma Gandhi as a psychological method to counter the British occupation in India circa the 1940s. The Arab Spring protests started with a peaceful demonstration. However, the protests turned violent when the regimes of Ben Ali, Mubarak, Qaddafi and Assad deployed military forces to crack down on protesters which later resulted in casualties. Do the youth activists in Malaysia perceive the Arab Spring as a violent protest? Table 6 below provides the answer. 
Table 6. Respondents' Perceptions that the Arab Spring was a Non-Violent Resistance Movement

\begin{tabular}{lcc}
\hline Category & Frequency & Percentage \\
\hline Strongly Disagree & 38 & 7.7 \\
Disagree & 66 & 13.4 \\
Neither Disagree Nor Agree & 113 & 22.9 \\
Agree & 162 & 32.9 \\
Strongly Agree & 114 & 23.1 \\
\hline
\end{tabular}

\section{Source: Field Research 2016}

114 respondents (23.1 percent) strongly agreed that the Arab Spring should be seen as a nonviolent resistance movement. 162 respondents (32.9) moderately supported the statement. Most of the arguments relied on the fact that the Arab Spring protests were joined by all layers of society the elderly, women, children, civil servants, students and general workers. All of them took to the streets unarmed and in a peaceful way without any intention to cause harm or chaos. Thus, for these respondents it is definitely unfair to consider the demonstrations as vicious acts. Since the question was relatively subjective, 22.9 percent of respondents seemed uncertain whether the Arab uprisings were violent or non-violent protests, while the remaining 104 respondents disagreed that the Arab Spring was a peaceful event.

\subsubsection{The Third Question: Perception that Economic Instability, the Unemployment Crisis and Autocratic Leadership Contributed to the Arab Spring}

It is popularly known that the tragedy of Bouazizi's death sparked the outraged protests in Tunisia which later spread to neighbouring countries starting with Egypt, Libya, the Yemen and Syria. However, deep inside the nature of the uprisings, protesters were actually trying to tell their respective ruling regimes that people were fed up with the increasing unemployment crisis due to economic instability, as well as the practice of dictatorship amongst the authorities (Anderson, 2011; Arieff, 2012; Owen, 2012). According to Gelvin (2012), the repressive nature of the Arab regimes and their suppression of citizen's rights, coupled with on-going corruption and the worsening economy were major causes leading to the Arab revolutions. From the respondents' own observations, the majority (74.7 percent) considered the economic downturn and political repression as the main contributing factors to the uprisings. For other respondents, 19.9 percent of them remained neutral while 5.4 percent believed that the Arab Spring was the hidden agenda of certain great powers to secure their interests in the countries involved; thus economic and political instability were rejected as reasons for the Arab Spring. Table 7 displays the responses given by Malaysian youth.

Table 7. Respondents' Perceptions that Economic Instability, the Unemployment Crisis and Autocratic Leadership Contributed to the Arab Spring

\begin{tabular}{lcc}
\hline Category & Frequency & Percentage \\
\hline Strongly Disagree & 11 & 2.2 \\
Disagree & 16 & 3.2 \\
Neither Disagree Nor Agree & 98 & 19.9 \\
Agree & 198 & 40.2 \\
Strongly Agree & 170 & 34.5 \\
\hline
\end{tabular}

Source: Field Research 2016 


\subsubsection{The Fourth Question: Perception that the Post-Arab Spring has Supported the} Democratisation Process in the Countries Involved

Democratisation, in its simplest form can be defined as political changes that move in a democratic direction. It is a process of developing, consolidating and establishing democracy in a nondemocratic state. The post Arab Spring phenomenon, to some observers such as Barbara Zollner, gives a new drive to the discussion of democratisation in the Middle East and North Africa region after being 'exceptional' for a decade ${ }^{9}$. However, the attempt to bring democracy to each of the Arab Spring's affected states was seen as somewhat unsuccessful, except for Tunisia which managed to show certain positive progress towards democracy. In the Yemen, Libya and Syria, the civil wars with intervention from foreign states continue to undermine the countries. Meanwhile in Egypt, the rule of Al-Sisi is perceived as the prolongation of Mubarak's dictatorship legacy. Thus, it is quite subjective to determine the status of democratisation in the Middle East post the Arab Spring events. Interestingly, 180 of the Malaysian youth activists (36.4 percent) chose to neither disagree nor agree that the post-Arab Spring has supported the democratisation agenda. 19.7 percent of respondents were of the opinion that the process of democratisation had still not happened, while 43.9 percent of respondents believed that the democratisation process has started in Tunisia and will later extend to its neighbouring Arab states. Table 7 gives details of the respondents' perceptions regarding the issue of democratisation in the post-Arab Spring.

Table 7. Respondents' Perceptions that the Post-Arab Spring has Supported the Democratisation Process in the Countries Involved

\begin{tabular}{lcc}
\hline Category & Frequency & Percentage \\
\hline Strongly Disagree & 21 & 4.3 \\
Disagree & 76 & 15.4 \\
Neither Disagree Nor Agree & 180 & 36.4 \\
Agree & 163 & 33.0 \\
Strongly Agree & 54 & 10.9 \\
\hline
\end{tabular}

Source: Field Research 2016

\subsection{Has the Arab Spring Phenomenon Influenced Malaysian Youth?}

This section will now explore the influence of the Arab Spring on Malaysian youth, specifically how the events impacted their attitudes towards the issues of regime change, democracy and political stability. Why these issues? Firstly, among policy makers, political scientists and academics, these are three issues that serve as a core discussion about post-Arab Spring studies in the affected states as evidenced by thousands of books, academic papers and conferences (Sadiki, 2015). Secondly, they are interconnected to each other. Regime change may lead to the establishment of a better government which will uphold the principle of democracy (free and fair election, basic civil liberties, effective power to govern). Once democracy is introduced, consolidated and maintained, it will indirectly lead to political stability in the country. There are examples from Indonesia and Tunisia. In Indonesia, the removal of Suharto in 1998, due to massive corruption and power abuses, successfully restored democracy and political stability. In Tunisia, the ousting of Ben Ali in 2011 managed to end several decades of dictatorship rule and drive the country progressively towards the process of democratic consolidation, as well as maintaining its stability after several hectic years following the launch of the Jasmine Revolution (Storm, 2014). Thirdly, there have been protests in Malaysia over the past few years which have pressured the current Prime Minister and his one party dominant government (Barisan Nasional) to step down. There is a rumour that the next general election may be held around the end of 2017 and the call for street demonstration is

\footnotetext{
${ }^{9}$ Fieldwork at the colloquium entitled "5 Years After the Arab Spring: The Implosion of Social Movements?", Birkbeck, University of London. 10 June 2016.
} 
now actively organised by opposition political parties ${ }^{10}$. Their aim is to have a regime change by any means and transform the current practice of 'semi-democracy' in Malaysia into a more open and democratic system. However, these activists will need significant support from youth in order to mobilise and secure any protests. The passion and energetic character of the youth make them a backbone of street protests and social movements around the world (Della Porta \& Diani, 2006). The potential involvement of a large number of youth in future political protests raises concern for the Malaysian ruling government. From the regime perspective, the act of street protest could possibly undermine the country's political stability and any attempt for political change should be funneled through a proper and legitimate channel - the election. For them, the opposition politicians and activists should never 'import' the elements of Arab Spring protest into Malaysia which may encourage youth to take to the street for the sake of regime change as occurred in previous protests $^{\uparrow 1}$. However, the opposition leaders, including Malaysian former Prime Minister, Dr Mahathir Mohamad, issued a counter argument which denied any 'indirect connection' between the Arab Spring and the Malaysian youth who participated in previous political rallies - the Bersih ${ }^{12}$. The issues mentioned have recently led to the polemics of the Arab Spring impact amongst Malaysian youth. Thus, to answer the question - has the Arab Spring phenomenon influenced Malaysian youth? - the researcher asked three major inter-linked questions in the questionnaire. The respondents' reactions to each question will be discussed in the following sections.

\subsubsection{Respondents' Views: Civil Disobedience and Street Protests during the Arab Spring have given Inspiration to Youth and Political Activists in Malaysia}

To describe Arab Spring events in their simplest form, the act of mass street protests and civil resistance in several Arab countries managed to topple the autocratic leaders and could fit into the current general narrative. In non-democratic states or less/partial/quasi democratic states the Arab Spring events are a relevant example to show how the sentiment of 'people's power' via street protest can overthrow corrupt regimes when ballot boxes are no longer effective due to regular manipulation by the regime (Saikal \& Acharya, 2014). Do Malaysian youth feel that street protests during the Arab Spring have inspired them to participate in civil protest in Malaysia? Table 9 below shows the respondents' reactions to the question. Out of 494 youth who answered the question, 69 respondents (14.0 percent) strongly believed that they were inspired by the protests of the Arab uprising, followed by 174 respondents (35.2 percent) who shared a similar attitude. 167 respondents (33.8 percent) gave a neutral response, while 65 respondents (13.2 percent) disagreed with the statement. Only 19 respondents (3.8 percent) totally rejected the idea of inspiration arising from the Arab Spring.

Table 9. Respondents' Views: Civil Disobedience and Street Protests during the Arab Spring have given Inspiration to Youth and Political Activists in Malaysia

\begin{tabular}{lcc}
\hline Category & Frequency & Percentage \\
\hline Strongly Disagree & 19 & 3.8 \\
Disagree & 65 & 13.2 \\
Neither Disagree Nor Agree & 167 & 33.8 \\
Agree & 174 & 35.2 \\
Strongly Agree & 69 & 14.0 \\
\hline
\end{tabular}

\section{Source: Field Research 2016}

\footnotetext{
${ }^{10}$ Fieldwork at the Coalition for Clean and Fair Election (Bersih) roadshow, Shah Alam, Malaysia. 3 November 2016.

11 "Malaysia's government accuses opposition of fomenting 'Arab Spring': Opposition leaders say new law banning street protests is more repressive than those in Burma and Zimbabwe". [Online] Available: https://www.theguardian.com/world/2011/nov/30/malaysia-goverment-opposition-arab-spring (May 9 2017).

${ }^{12}$ Fieldwork at the Coalition for Clean and Fair Election (Bersih) roadshow, Shah Alam, Malaysia. 3 November 2016. The statement was quoted directly from Dr Mahathir Mohamad's speech at the event.
} 
To investigate the reason why the selected youth in Malaysia support the act of civil disobedience in the aftermath of the Arab Spring which led them to take to the streets, the researcher conducted several interviews with youth leaders from different NGOs and political parties. According to a statement from one of the youth leaders, "our youth are tired of hearing of more and more power abuses and corruption being 'enjoyed' by the regime, therefore participation in any political rally seems inevitable and serves as the only way to pressure the government for political and electoral reform. Indirectly, it also raises awareness with other Malaysians, especially among the youth that being politically apathetic or remaining silent is not going to change anything. If Arab citizens have their own Arab Spring, we should be proud of our own Bersih movements" ${ }^{13}$. This statement suggests that the Arab Spring did somehow influence the thoughts of Malaysian youth activists regarding the need to organise a large-scale political protest against a corrupt government.

\subsubsection{Respondents' Views: Power Transfer through Civil Disobedience and Street Protests does not Suggest a Positive Political Transition}

To further investigate the impact of the Arab Spring on the attitudes of Malaysian youth, the researcher asked a potentially more 'provocative' question to determine their stand on the act of street protest for political change - Do Malaysian youth consider the act of civil disobedience beneficial for Malaysia's political transition? As shown in table 10 below, 61.4 percent of respondents Agree that power transfer through civil disobedience does not suggest a positive political change. 29.6 respondents chose to remain neutral regarding the question while 9.1 believe that street protest could potentially bring productive political reform in the country.

Table 10. Respondents' Views: Power Transfer through Civil Disobedience and Street Protests does not Suggest a Positive Political Transition

\begin{tabular}{lcc}
\hline Category & Frequency & Percentage \\
\hline Strongly Disagree & 10 & 2.0 \\
Disagree & 35 & 7.1 \\
Neither Disagree Nor Agree & 146 & 29.6 \\
Agree & 158 & 32.0 \\
Strongly Agree & 145 & 29.4 \\
\hline
\end{tabular}

Source: Field Research 2016

Based on the interviews, the explanation for this pattern of data can perhaps be explained by the significant change from 'Arab Spring hope' to 'Arab Winter uncertainties' as has occurred in current political affairs in Egypt, Syria, the Yemen and Libya. As argued by Hardy (2013), a smooth political transition cannot happen in one night, even though an autocratic regime has been replaced with people's power. Sometimes it can take hundreds of years to consolidate democracy before a country can become a respectable democratic state. Thus, after having seen all the news about the ongoing conflicts in the Middle East and North Africa in the aftermath of the Arab Uprisings, what options do Malaysian youth have in order to achieve political reform? The following section will reveal the answer.

\subsubsection{Respondents' Views: Democratic Political System and Associated Elections are the Best Medium to Determine the Direction of the Country's Leadership}

Since its independence in 1957, Malaysia has periodically experienced general elections in order to choose a new government after every five years of fixed-term rule. Of the 13 general elections held, the ruling coalition party - $\mathrm{BN}$ - has dominated all the prime ministerial and ministerial positions and has won the majority of seats in parliament in the first-past-the-post system. Some scholars, for

${ }^{13}$ Interview with a political youth activist. Kuala Lumpur, Malaysia. 25 June 2016 
example Case (1993, 2007 and 2017) and Diamond (2012) describe this situation as a competitive authoritarian or semi-democratic practice since there were claims by opposition parties that the regime had been manipulating election results in order to remain in power. Despite these local circumstances, coupled with the ongoing political issues in the Middle East and North Africa in the post-Arab Spring context, it seems that democracy is still at the heart of the majority of Malaysian youth (67.6 percent) who considered elections and a democratic political system as the most practical and relevant means for any political change in the country. 24.1 percent of Malaysian youth were not certain whether democracy and elections were the best medium to determine the future of national politics. However, given the bad record of practicing a free and fair election in Malaysia, 8.3 percent of respondents rejected the value of elections and a democratic political system to regulate the country's leadership. Table 11 shows details of respondents' reactions about the relevance of a democratic political system and voting.

Table 11. Respondents' Views: Democratic Political System and Associated Elections are the Best Medium to Determine the Direction of the Country's Leadership

\begin{tabular}{lcc}
\hline Category & Frequency & Percentage \\
\hline Strongly Disagree & 7 & 1.4 \\
Disagree & 34 & 6.9 \\
Neither Disagree Nor Agree & 119 & 24.1 \\
Agree & 199 & 40.3 \\
Strongly Agree & 135 & 27.3 \\
\hline
\end{tabular}

Source: Field Research 2016

\section{Lessons from the Arab Spring}

Every major historical event that occurs in the world undoubtedly produces some valuable lessons for humankind. The same principal applies in the case of the Arab Spring. There is significant research which highlights the lessons that can be drawn from the Arab Spring - for instance by Filiu (2011), Sadiki (2015), Roberts et al (2016) and Ghanem (2016). However, none of these publications discuss the perspective of countries beyond the Middle East and North Africa region. Hence, after all these years of observation and perception relating to the Arab Spring, have Malaysian youth learnt something from these momentous events? In order to answer this question, the researcher has provided three statements in the questionnaire which relate to the issue of the "Malaysian Spring" and the merits of political stability. The following sections will highlight the lessons from the Arab Spring for Malaysian youth activists.

\subsection{Malaysia Does Not Need Any 'Arab Spring'-Style Public Protests and Street Demonstrations}

Despite Malaysia's current shaky political ground and economic situation, 254 Malaysian youth (51.5 percent) agreed that the country does not need to emulate Arab Spring-style protests - for the sake of maintaining peace and political stability. For these young people, the politics and economic conditions in Malaysia are very different from the Arab world. Thus, to organise similar protests to those seen in the Arab Spring seems pointless. Furthermore, Malaysia is currently recognised as a moderate Muslim nation among Organisation of Islamic Cooperation (OIC) members and the western world. Thus, any action which could damage this reputation should be avoided. The postArab Spring in Syria, Libya, Egypt and the Yemen has led these respondents to consider that a plan for political change should include every layer of society - be it secular groups, Islamists, left wingers or nationalists. In contrast, 116 Malaysian youth (23.5 percent) supported the act of street demonstrations as long as the existing government of Najib Razak remained in power, although not with the same momentum as in the Arab Spring. The act of civil disobedience for them functions as a checks and balances mechanism to the ruling government in order to improve the quality of 
democracy. The remaining 123 youth (24.9 percent) were neutral to the statement. Table 13 provides detail of the respondents' reactions to the issue of Malaysia and 'Arab Spring'-style political rallies.

Table 13. Respondents' Views: Malaysia Does Not Need Any 'Arab Spring'-Style Public Protests and Street Demonstrations

\begin{tabular}{lcc}
\hline Category & Frequency & Percentage \\
\hline Strongly Disagree & 46 & 9.3 \\
Disagree & 70 & 14.2 \\
Neither Disagree Nor Agree & 123 & 24.9 \\
Agree & 132 & 26.8 \\
Strongly Agree & 122 & 24.7 \\
\hline
\end{tabular}

Source: Field Research 2016

\subsection{Truth about the Polemics of the "Malaysian Spring"}

In the beginning of the article, the researcher highlighted some polemics about the potential of the "Malaysian Spring" to happen in the future due to a series of civil resistance actions by the prodemocracy movement group - the Bersih - from 2011 until recently (2016). Pro-government politicians and some foreign journalists accused these demonstrations of being a kind of indirect effort to topple the existing regime which could also be considered a "Malaysian Spring". However, the findings from this research indicate that many Malaysian youth who have participated in past demonstrations (145 respondents) are not clear whether the efforts by the Bersih movement should be viewed as an attempt to create a "Malaysian Spring". However, 144 respondents agreed that the Bersih movement somehow tried to launch an Arab Spring-style protest in Malaysia, although there is no solid evidence to support this view which led to its rejection by 93 respondents. Less than 12 percent of respondents intensely agreed or disagreed about this polemic. Table 14 records all responses regarding the polemics of the "Malaysian Spring".

Table 14. Respondents' Views Whether the Series of Protest Events Organised by the Bersih were an Indirect Effort to Create a "Malaysian Spring"

\begin{tabular}{lcc}
\hline Category & Frequency & Percentage \\
\hline Strongly Disagree & 58 & 11.7 \\
Disagree & 93 & 18.8 \\
Neither Disagree Nor Agree & 145 & 29.4 \\
Agree & 144 & 29.1 \\
Strongly Agree & 54 & 10.9 \\
\hline
\end{tabular}

Source: Field Research 2016

\subsection{Political Stability is Valued Above a Regime Change Via Street Protest}

The final lesson that can be learnt from the Arab Spring from the perspective of the sample of Malaysian youth is that the merits of political stability should always be prioritised, even though the country is facing economic and political challenges. The act of mass street protest is believed to temporarily affect the country's peace, stability and the normal daily lives of its citizens as can be seen from the series of Bersih events when all major roads, public places and buildings were forced to close for several days. If one looks at the post-Arab Spring in Libya, Syria and the Yemen, the consequences are very serious with on-going conflicts and wars. However, these countries were in a relatively better condition before the launch of public protest which later turned into the popular 
Arab Spring phenomenon. As shown in Table 12, the majority of respondents (54.8 percent) preferred to avoid any attempt at political change via street demonstrations for the sake of maintaining the current political stability in Malaysia. 28.5 percent of respondents gave a balanced reaction against 16.6 percent of 'hardcore' activists who were firmly against the statement. Overall, the research indicates that a high proportion of Malaysian youth favour maintaining political stability which indirectly makes them less interested in participating in street protest that could potentially harm the country's peace.

Table 12. Respondents' Views: Political Stability is Valued Above a Regime Change Via Street Protest

\begin{tabular}{lcc}
\hline Category & Frequency & Percentage \\
\hline Strongly Disagree & 30 & 6.1 \\
Disagree & 52 & 10.5 \\
Neither Disagree Nor Agree & 141 & 28.5 \\
Agree & 169 & 34.2 \\
Strongly Agree & 102 & 20.6 \\
\hline
\end{tabular}

\section{Source: Field Research 2016}

\section{Conclusion}

Nearly six years have passed since the launch of the Arab Spring. Throughout this period, people's perceptions towards the events have also changed considerably. As in the case of Malaysian youth, the majority of them were aware of the events and they have a range of perceptions about the uprisings with new social media, such as Facebook and Twitter, playing an important role in providing them with information and knowledge about the Arab Spring. The Arab Spring was widely perceived as the Arab people's upheaval against their respective autocratic rulers which involved the actions of non-violent resistance movements. Economic instability, an unemployment crisis and dictatorship were observed by Malaysian youth as factors that contributed to the uprisings. Nevertheless, these youth are relatively uncertain about the prospect of democracy in the region and somehow feel that the uncertainties in the Arab world will eventually lead to another wave of democratic uprisings in the future. The influence of the Arab Spring events can be traced by a number of Malaysian youth activists who believe that they were inspired by the enormous turn-out of Arab youth during the 'Arab Spring' civil protests. They believe that the same protests could also effectively serve as a way to voice their objection to the 'competitive autocratic' regime in Malaysia. This motivation came when they watched the overthrow via people's power of several former Arab rulers in the Middle East and North Africa. Nevertheless, the post Arab Spring phenomenon has also brought valuable lessons for Malaysian youth. The majority of them favour political stability rather than regime change after witnessing the traumatic conflicts in Egypt, Libya, Syria and the Yemen in the aftermath of the Arab Spring. The polemics on the issue of the "Malaysian Spring" and the Bersih movement seem to unfold when significant numbers of Malaysian youth activists remain neutral or disagree with such claims. Overall, this empirical research found that the majority of Malaysian youth support free and democratic elections as a relevant medium for political change rather than to overthrow the current regime via civil disobedience.

\section{References}

Anderson, L. (2011). Demystifying the Arab Spring: Parsing the Differences Between Tunisia, Egypt, and Libya. Retrieved from https://www.foreignaffairs.com/articles/libya/2011-04- 03/demystifying-arab-spring

Arieff, A. (2012). Political Transition in Tunisia and Egypt: Unrest and Revolution, edited by De Leon, J.C and Jones, C.R, 1-43. New York: Nova Science.

Case, W. (1993). Semi-Democracy in Malaysia: Withstanding the Pressures for Regime Change. Pacific Affairs, 66 (2), 183-205. 
Case, W. (2007). Malaysia: The Semi-Democratic Paradigm. Asian Studies Review, 17 (1), 75- 82.

Case, W. (2017). Stress Testing Leadership in Malaysia: The 1MDB Scandal and Najib Tun Razak. The Pacific Review,1-23.

Creswell, J.W. (2014). Research Design: Qualitative, Quantitative and Mixed Methods Approaches (4 ${ }^{\text {th }}$ ed.). Los Angeles: Sage.

Currie, K. (2012). Asia and the Arab Spring. Retrieved from http://www.iemed.org/observatori- en/areesdanalisi/arxius-adjunts/anuari/med.2012/currie_en.pdf

Della Porta, D and Diani, M. (2006). Social Movement: An Introduction ( $2^{\text {nd }}$ ed.). Victoria: Blackwell Publishing.

Diamond, L. (2012). The Coming Wave: China and East Asian Democracy. Journal of Democracy, 23 (1), 5-13.

Fisher, J. (2012). Could Street Protests Herald a Malaysian Spring? Retrieved from http://www.bbc. co.uk/news/world-asia-pacific-18058036.

Freedom House. (2015). Freedom in the World. Retrieved from https://freedomhouse.org/report- types/freedomworld\#

Gelvin, J.L. (2012). The Arab Uprisings: What Everyone Needs to Know. Oxford: Oxford University Press.

Ghanem, H. (2016). The Arab Spring Five Years Later: Toward Greater Inclusiveness. Washington: Brookings Institution Press.

Hardy, R. (2013). Democracy or Disorder? The Four Lessons of the Arab Spring. Retrieved from http://www.bbc.co.uk/news/world-middle-east-23266790.

Kassab, E.S. (2014). Critics and Rebels: Older Arab Intellectuals Reflect on the Uprisings. British Journal of Middle Eastern Studies, 41 (1), 8-27.

Krejcie, V.R and Morgan, W.D. (1970). Determining Sample Size for Research Activities. Educational and Psychological Measurement, 30, 607-610.

Osman, B. (2012). The Arab Spring: Malaysian Responses. IAIS Malaysia. 743-746.

Owen, R. (2012). The Rise and Fall of Arab Presidents for Life, Massachusetts: Harvard University Press.

Pang, K.T. (2015). Social Policy and Social Development in Wiess, M.L ed. Routledge Handbook of Contemporary Malaysia. London: Routledge.

Pierre-Filiu, J. (2011). The Arab Revolution: Ten Lessons from the Democratic Uprising. Oxford: Oxford University Press.

Roberts, A. et al. (2016). Civil Resistance in the Arab Spring: Triumphs and Disasters. Oxford: Oxford University Press.

Roy, O. (2012). The Transformation of the Arab World. Journal of Democracy, 23 (3), 5-18.

Sadiki, L. (2015). Towards A 'Democratic Knowledge' Turn? Knowledge Production in The Age of The Arab Spring. The Journal of North African Studies, 20 (5), 702-721.

Saikal, A. and Acharya, A. ed. (2014). Democracy and Reform in the Middle East and Asia: Social Protest and Authoritarian Rule After the Arab Spring. London: I.B. Touris.

Storm, L. (2014). Party Politics and the Prospects for Democracy in North Africa. Colorado: Lynne Rienner. 